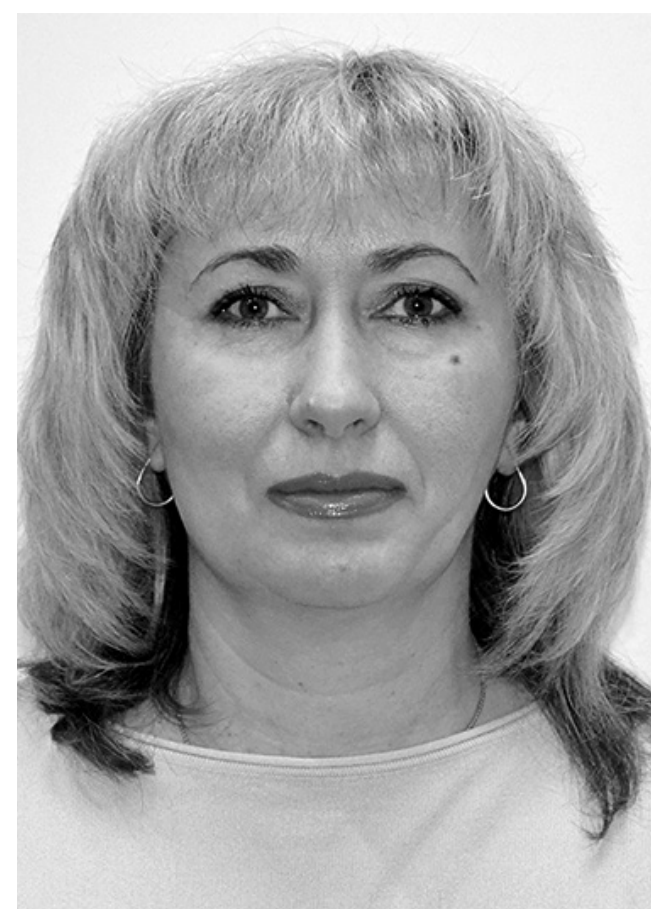

UDC: 351.72:336.14

DOI: https://doi.org/10.32689/2617-

2224-2020-1(21)-192-202

Марченко Людмила Юріївна, аспірант кафедри управління персоналом та економіки праиі ХарРІ НАДУ, заступник начальника управління-начальник відділу видатків Управління державної казначейської служби України у м. Харкові Харківської області, 61051, м. Харків, вул. Клочківська, 276-Б, тел.: +38 (067) 77747 05, e-mail: marcheluda@ gmail.com

ORCID:0000-0003-3577-0630

\section{Марченко Людмила Юръевна,}

аспирант кафедры управления персоналом и экономики труда ХарРИ НАГУ, заместитель начальника управления-начальник отдела расходов Управления Государственной казначейской службы Украины в г. Харькове Харьковской области, 61051, 2. Харьков, ул. Клочковская, 276-Б, тел.: +38 (067) 77747 05, e-mail: marcheluda@ gmail.com

ORCID:0000-0003-3577-0630

\section{Marchenko Lyudmila Yuryevna}

post-graduate student of Personnel Management and Labour Economics Department, KRI NAPA, Deputy Head of Taxation Administration-Head of Department of Expenditures, Administration of State Treasury Service of Ukraine in Kharkiv City, Kharkiv Region, 61051, Kharkiv, Str. Klochkivska, 276-B, tel: +38 (067) 77747 05, e-mail: marcheluda@gmail.com

ORCID:0000-0003-3577-0630

\title{
ДЕРЖАВНА КАЗНАЧЕЙСЬКА СЛУЖБА УКРАЇНИ ЯК СУБ'ЄКТ НАДАННЯ ПУБЛІЧНИХ ПОСЛУГ В СУЧАСНОМУ - ПОСТМОДЕРНОМУ СУСПІЛЬСТВІ (АРХЕТИПНИЙ ПІДХІД)
}

Анотація. Схарактеризовано ознаки постмодернового суспільства: зменшення ролі матеріального виробництва; стрімкий розвиток сектору послуг та інформації; зміна характеру людської діяльності та типів ресурсів, що залучаються до виробництва; суттєва модифікація традиційної соціальної 
структури, і наголошено на важливості ролі архетипів. Архетипіка як наука та архетипи розглядаються як рушій прогресу в сучасному процесі державотворення. Визначено завдання та повноваження Державної казначейської служби України відповідно до існуючих законодавчих актів. Узагальнено теоретичні підходи до виконання функцій Державної казначейської служби України. Обгрунтовано включення обслуговуючої функції. Запропоновано закріпити на законодавчому рівні такі функції Державної казначейської служби України: нормотворча; обслуговуюча; облікова; контрольна; профілактична (превентивна); інформаційна; управлінська. Зазначено, що в постмодерному суспільстві ефективність функціонування Державної казначейської служби України залежить від професійного, якісного складу персоналу. Зазначено, що людина - працівник Казначейства, який виконує завдання і функції, покладені на Казначейство, відіграє досить важливу роль в порядку взаємодії з урядом, органами державної влади та органами місцевого самоврядування, бюджетними установами, організаціями, підприємствами, фізичними особами - підприємцями та громадянами з метою прийняття своєчасних та ефективних управлінських рішень. Обгрунтовано необхідність професійного навчання державних службовців на основі компетентнісного підходу. Визначено сучасні форми навчання та освітні програми, за якими відбувається підвищення кваліфікації державних службовців. Проаналізовано процедуру прийняття на роботу до органів Казначейства на конкурсних засадах, яка засвідчує проблему в частині тестових завдань, які мають не предметний, а загальний характер. Рекомендовано наблизити зміст завдань в тестах до виконуваних функцій в органах Казначейства.

Ключові слова: архетипи, Державна казначейська служба України, постмодерне суспільство, суб’єкт, функції.

\section{ГОСУДАРСТВЕННАЯ КАЗНАЧЕЙСКАЯ СЛУЖБА УКРАИНЫ КАК СУБЪЕКТ В СОВРЕМЕННОМ - ПОСТМОДЕРНОМ ОБЩЕСТВЕ (АРХЕТИПИЧЕСКИЙ ПОДХОД)}

Аннотация. Охарактеризованы признаки постмодернистского общества: уменьшение роли материального производства; стремительное развитие сектора услуг и информации; изменение характера человеческой деятельности и типов ресурсов, привлекаемых к производству; существенная модификация традиционной социальной структуры, и отмечена важность роли архетипов. Архетипика как наука и архетипы рассматриваются как двигатель прогресса в современном процессе создания государства. Определены задачи и полномочия Государственной казначейской службы Украины в соответствии с существующими законодательными актами. Обобщены теоретические подходы к выполнению функций Государственной казначейской службы Украины. Обосновано включение обслуживающей функции. Предложено закрепить на законодательном уровне следующие функции Государственной казначейской службы Украины: нормотворческая; обслуживающая; учетная; контрольная; профилактическая (превентивная) ин- 
формационная; управленческая. Отмечено, что в постмодерном обществе эффективность функционирования Государственной казначейской службы Украины зависит от профессионального, качественного состава персонала. Отмечено, что человек - работник Казначейства, который выполняет задачи и функции, возложенные на Казначейство, играет важную роль в порядке взаимодействия с правительством, органами государственной власти и органами местного самоуправления, бюджетными учреждениями, организациями, предприятиями, физическими лицами - предпринимателями и гражданами с целью принятия своевременных и эффективных управленческих решений. Обоснована необходимость профессионального обучения государственных служащих на основе компетентностного подхода. Определены современные формы обучения и образовательные программы, по которым происходит повышение квалификации государственных служащих. Проанализирована процедура принятия на работу в органы Казначейства на конкурсной основе, отмечена проблема в содержании тестовых заданий, которые носят не предметный, а общий характер. Рекомендуется приблизить содержание заданий в тестах к выполняемым функциям в органах Казначейства.

Ключевые слова: архетипы, Государственная казначейская служба Украины, постмодерное общество, субъект, функции.

\section{STATE TREASURY SERVICE OF UKRAINE AS A SUBJECT IN A MODERN - POSTMODERN SOCIETY (ARCHETYPIC APPROACH)}

Abstract. The article presents the characteristic features of a postmodern society: the diminishing role of the material production; rapid development of the services and information sector; changing the nature of human activity and the types of resources involved in production; a significant modification of the traditional social structure, and emphasized the importance of the role of archetypes. Archetype as a science and archetypes are seen as a driving force for progress in the modern process of the state formation. The tasks and powers of the State Treasury Service of Ukraine in accordance with the existing legislative acts have been determined. Theoretical approaches to the fulfillment of the functions of the State Treasury Service of Ukraine are generalized. The inclusion of a service function is justified. The following functions of the State Treasury Service of Ukraine are envisaged to be fixed on the legislation: rulemaking; servicing; accounting; control; prophylactic (preventive); informational; administrative. It is noted that in the postmodern society the effectiveness of the functioning of the State Treasury Service of Ukraine depends on the professional, quality staff. It is noted that the person - the employee of the Treasury, who performs the tasks and functions assigned to the Treasury, plays a rather important role in the interaction with the government, state authorities and local self-government bodies, budgetary institutions, organizations, enterprises, individuals - entrepreneurs and citizens making timely and effective administrative decisions. The neces- 
sity of the professional training of the civil servants on the basis of competence approach is substantiated. The modern forms of education and educational programs are defined. The author analyzes the procedure for hiring for the Treasury on a competitive basis, certifying the problem in terms of test tasks that are not substantive, but general in nature. It is recommended to approximate the content of the tasks in the tests to the functions performed in the bodies of the Treasury.

Keywords: archetypes, State Treasury Service of Ukraine, postmodern society, subject, functions.

Постановка проблеми. В останні роки в Україні відбуваються процеси трансформації та реформування в органах публічного управління, зокрема в органах Державної казначейської служби України (далі - органи Казначейства). Розвиток постмодерного суспільства супроводжується ефективним та результативним наданням публічних послуг, тому виникає необхідність дослідження нових підходів щодо визначення функцій органів Казначейства. Впровадження інформаційних технологій в постмодерному суспільстві актуалізує питання професійного навчання працівників органів Казначейства.

Аналіз останніх досліджень і публікацій. Вагомий внесок у розвиток теоретичних положень архетипіки зробили такі сучасні вітчизняні науковці: О. Амосов, Е. Афонін, Н. Гавкалова, В. Омел'яненко, О. Сушій та ін.

У свою чергу, дослідженню питань, пов’язаних з функціями органів Казначейства здійснювали ряд науковців, а саме: І. Ю. Клітенко, С. Я. Кондратюк, О. І. Прекрасна, В. I. Стоян, Н. І. Сушко, Л. І. Штригель та інші.

Однак у зв'язку з постійними трансформаційними процесами в ор- ганах Казначейства необхідно більш детально систематизувати функції органів Казначейства.

Мета статті. Систематизація функцій Державної казначейської служби як суб'єкта надання публічних послуг в умовах постмодерного суспільства. Обгрунтування нових підходів щодо якості професійного навчання працівників Казначейства.

Виклад основного матеріалу дослідження. Постмодернізм - це культура постіндустріального, інформаційного суспільства, а також він виходить за межі культури та тією чи іншою мірою проявляється у всіх сферах суспільного життя, включаючи економіку та політику.

Широке використання терміну “постмодернізм" відзначається наприкінці 60 -х років для характеристики новацій у мистецтві, літературі, а також трансформації у соціально-економічній, технологічній і соціально-політичній сферах [1].

При постмодернізмі головним принципом розвитку є одержання необхідної освіти, інформації, знання $з$ метою опанування наукоємних та інтелектуальних технологій, які використовує суспільство. Характерними ознаками постіндустріального суспільства $€$ : зменшення ролі 
матеріального виробництва; стрімкий розвиток сектору послуг та інформації; зміна характеру людської діяльності та типів ресурсів, що залучаються до виробництва; суттєва модифікація традиційної соціальної структури. Також в постіндустріальному суспільстві досить важливою є взаємодія між людьми.

В постмодерному суспільстві важливу роль у розвитку державного управління відіграє теорія архетипів. В наукових дослідженнях спостерігається великий інтерес до міфу, архетипу, їхньої сутності та сфери функціонування. Вони можуть набувати нових форм, отримувати нові трактування та пояснення, але при цьому зберігають свою первісну сутність. Важливим чинником формування світогляду та подальшого розвитку націй є архетипи. Багато вчених вважають, що архетипи є однаковими для всього людства, однак під впливом історичних обставин і потреб кожної нації видозмінюються.

Поняття “міфу”, “архетипу” лежать в одній площині й тісно пов’язані один із одним. Міф є результатом колективної взаємодії та універсальною базою для створення символів, сюжетів та образів; у міфі реальність має міфологічне значення, а час - циклічну структуру; міф виконує пізнавальну й освітню функції. За теорією К. Г. Юнга, архетипи - наріжні глибинні смислові зв'язки, що утворюють вихідні, споконвічні засади культури людства в цілому та відносно окремих локальних історичних культур, спільнота яких і становить всесвітню історію [2]. Архетип - це найголовніше по- няття колективного несвідомого, який характеризується постійним розвитком та адаптацією до історичного періоду.

В сучасному постмодерному суспільстві досить цікавим суб'єктом надання публічних послуг дослідження 3 точки зору дослідження архетипних та міфологічних засад є Державна казначейська служба України (далі - Казначейство), яка в своєму історичному розвитку пройшла певну кількість етапів.

Історично Казначейство виконувало декілька функцій: відповідало за збереження багатства держави; було місцем, де збиралися платежі держави і з якого держава здійснювала виплати; відповідало (під королівським наглядом) за чеканку монет; а також виконувало функцію облікового відомства.

Наявність окремого уповноваженого органу в системі виконавчої влади держави, який відповідає за розробку та здійснення державної фінансової політики, є закономірністю для всіх епох і держав.

На сьогодні Казначейство є центральним органом виконавчої влади, діяльність якого спрямовується і координується Кабінетом Міністрів України через Міністра фінансів і який реалізує державну політику у сферах казначейського обслуговування бюджетних коштів, бухгалтерського обліку виконання бюджетів.

У процесі здійснення операцій 3 бюджетними коштами Казначейство діє як злагоджений механізм і виконує наступні завдання: реалізацію державної політики у сферах казначейського обслуговування бюджетних коштів, бухгалтерського обліку 
виконання бюджетів; внесення на розгляд Міністра фінансів пропозицій щодо забезпечення формування державної політики у зазначених сферах [3].

Казначейство відповідно до покладених завдань:

1. Узагальнює практику застосування законодавства 3 питань, що належать до його компетенції, розробляє пропозиції щодо вдосконалення законодавчих актів, актів Президента України та Кабінету Міністрів України, нормативно-правових актів міністерств та в установленому порядку подає їх Міністру фінансів;

2. Забезпечує казначейське обслуговування бюджетних коштів на основі ведення єдиного казначейського рахунка, відкритого у Національному банку ( розрахунково-касове обслуговування розпорядників та одержувачів бюджетних коштів; відкриття та закриття рахунків; повернення коштів, помилково або надміру зарахованих до бюджету; бюджетне відшкодування податку на додану вартість; формування та ведення єдиного реєстру розпорядників (одержувачів) бюджетних коштів і бази даних мережі розпорядників (одержувачів) бюджетних коштів; реєстрація та облік бюджетних зобов'язань; проведення платежів розпорядників (одержувачів) бюджетних коштів; безспірне списання коштів з державного та місцевих бюджетів або боржників на підставі рішення суду; здійснює покриття тимчасових касових розривів місцевих бюджетів та Пенсійного фонду України; веде бухгалтерський облік операцій з виконання державного та місцевих бюджетів; зводить і складає звітність про виконання державного, місцевих, зведених місцевих і зведеного бюджетів та подає звітність органам законодавчої, виконавчої влади, місцевим фінансовим органам; складає консолідовану фінансову звітність про загальний майновий стан і результати діяльності суб'єктів державного сектору та бюджетів та інше);

3. Здійснює в межах повноважень, передбачених законом, контроль за веденням бухгалтерського обліку надходжень і витрат державного та місцевих бюджетів, складенням та поданням розпорядниками та одержувачами бюджетних коштів фінансової і бюджетної звітності; бюджетними повноваженнями під час зарахування надходжень бюджету; відповідністю кошторисів розпорядників бюджетних коштів показникам розпису бюджету; відповідністю взятих розпорядниками бюджетних коштів бюджетних зобов'язань відповідним бюджетним асигнуванням, паспорту бюджетної програми (у разі застосування програмно-цільового методу в бюджетному процеci); відповідністю платежів узятим бюджетним зобов'язанням та відповідним бюджетним асигнуванням; дотриманням правил за операціями з бюджетними коштами в іноземній валюті; дотриманням порядку проведення лотерей з використанням електронних систем прийняття сплати за участь у лотереї в режимі реального часу; дотриманням розпорядниками та одержувачами бюджетних коштів, іншими клієнтами вимог законодавства у сфері закупівель в частині наявності, відповідності та правильності оформлення документів. 
Наведені вище завдання Казначейства визначають основні напрями діяльності служби, але немає функціонального забезпечення ii діяльності. Базою цьому слугує передусім визначення функцій Казначейства, які на жаль в законодавстві невизначено.

Клітенко І. Ю. розглядає 7 функцій відповідно до напрямів діяльності органів Казначейства та поділяє їх за формами на класичні (розрахунково-касова, контрольна, облікова, управлінська, нормотворча) i неокласичні (стабілізаційна, оптимізаційна) [4].

В своїй роботі Прекрасна О. I. зазначає, що при достатньо широкій варіативності в юридичній літератуpi визначення видів функцій, більшість авторів одностайні у виділенні таких функцій органів державної влади як прогнозування, планування, організація, керування, регулювання, координація, облік, контроль. Внаслідок співставлення основних повноважень Казначейства з означеними вище видами функцій було виділено 7 функцій: політична, інформаційна, контрольна, нормотворча, облікова, профілактична (превентивна), правоохоронна [5].

На нашу думку заслуговує уваги дослідження Н. I. Сушко, яка за результатами аналізу діючого законодавства зазначає, що Казначейство виконує як спеціальні так і загальні функції управління. Вона акцентує увагу, що спеціальними функціями Каз начейства є напрями діяльності,

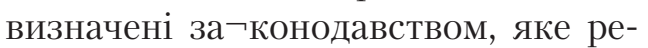
гулює питання реалізації державної політики в сферах казначейського обслуговування бюджетів та обліку i звітності їх виконання. Виконання функцій забезпечується шляхом здійснення відповідних процесів, які містять взаємопов'язані операції та проводяться у ви $з$ наченій послідовності під час виконання повноважень працівниками структурних підрозділів. При цьому кожна функція здійснюється Казначейством відповідно до технологічного регламенту виконання функціональних процесів. Наразі Казначейством розроблено та затверджено технологічні регламенти за такими функціями: “Обслуговування бюджетів, розпорядників та одержувачів бюджетних коштів, інших клієнтів”; “Управління фінансовими ресурсами”; “Ведення бухгалтерського обліку та складання звітності" та “Здійснення повноважень розпорядника коштів” [6].

Після розгляду та проведення аналізу різних наукових думок та підходів систематизуємо функції з точки зору функцій притаманних органам державної влади. На нашу думку відповідно до повноважень Казначейства, визначених Положенням про Державну казначейську служби України, можна визначити 7 функцій Казначейства: нормотворча; обслуговуюча; облікова; контрольна; профілактична (превентивна); інформаційна; управлінська.

Нами вперше запропоновано закріпити обслуговуючу функцію, яка полягає в виконанні наступних повноважень органами Казначейства: відкриття та закриття рахунків за надходженнями, видатками, а також у системі електронного адміністрування податків; розрахунково-касове обслуговування розпорядників (одержувачів) бюджетних коштів; 
розподіл бюджетних коштів між державним бюджетом, місцевими бюджетами, загальним та спеціальним фондами бюджету відповідно до нормативів відрахувань; бюджетне відшкодування податку на додану вартість; формування і доведення до розпорядників (одержувачів) бюджетних коштів витягів з розпису державного бюджету, витягів з розпису державного бюджету за територіями, територіальний розподіл за міжбюджетними трансфертами та зміни до них; здійснення операцій 3 повернення кредитів, наданих за рахунок коштів державного та місцевих бюджетів; проведення відповідних розрахунків між державним та місцевими бюджетами, між місцевими бюджетами, а також між учасниками бюджетного процесу та суб'єктами господарювання; здійснення платежів за дорученнями розпорядників (одержувачів) бюджетних коштів відповідно до законодавства, в тому числі платежі, пов'язані з виконанням зобов'язань, взятих під державні та місцеві гарантії; перерахування міжбюджетних трансфертів; здійснення операцій в іноземній валюті для проведення витрат розпорядників (одержувачів) бюджетних коштів; здійснення погашення та обслуговування державного боргу, проведення платежів, пов'язаних 3 виконанням гарантійних зобов'язань держави, в національній та іноземній валютах за дорученням Мінфіну; забезпечення казначейського обслуговування бюджетних коштів під час реалізації спільних з міжнародними фінансовими організаціями проектів; обслуговування коштів фондів загальнообов'язкового державного соціального і пенсійного страхування, інших клієнтів та коштів єдиного внеску на загальнообов'язкове державне соціальне страхування.

За результатами проведеного дослідження пропонуємо деталізувати повноваження Казначейства відповідно до узагальнених функцій та закріпити на законодавчому рівні, тобто прийняти закон або нормативний акт, щодо закріплення функцій Казначейства.

У сучасному постмодерному суспільстві Казначейство $є$ досить активним гравцем, а тому людина - працівник Казначейства, який виконує завдання і функції покладені на Казначейство, відіграє досить важливу роль в порядку взаємодії з урядом, органами державної влади та органами місцевого самоврядування, бюджетними установами, організаціями, підприємствами, фізичними особами - підприємцями та громадянами 3 метою прийняття своєчасних та ефективних управлінських рішень.

Ефективність функціонування Казначейства залежить від професійного, якісного складу персоналу, зокрема управлінців. В останні роки всі державні службовці, зокрема працівники Казначейства, можуть реалізувати своє право на професійне навчання відповідно до Положення про систему професійного навчання державних службовців, голів місцевих державних адміністрацій, їх перших заступників та заступників, посадових осіб місцевого самоврядування та депутатів місцевих рад затвердженого постановою Кабінету Міністрів України від 06.02.2019 р. № 106 [7]. Існують певні форми 
професійного навчання: підготовка (успішне виконання учасниками професійного навчання відповідної освітньо-професійної програми, що є підставою для присудження ступеня вищої освіти за рівнем магістра за спеціальностями, необхідними для професійної діяльності на державній службі та службі в органах місцевого самоврядування, зокрема за спеціальністю 281 "Публічне управління та адміністрування” галузі знань "Публічне управління та адміністрування”); підвищення кваліфікації (набуття учасниками професійного навчання нових та/або вдосконалення раніше набутих компетентностей у межах професійної діяльності або галузі знань); стажування (набуття учасниками професійного навчання практичного досвіду виконання завдань та обов'язків у професійній діяльності або галузі знань); самоосвіта (самоорганізоване здобуття учасниками професійного навчання певних компетентностей, зокрема під час повсякденної діяльності, пов'язаної з професійною, громадською або іншою діяльністю, дозвіллям).

На нашу думку також існує проблемне питання, щодо прийняття та зарахування на державну службу, зокрема до органів Казначейства в частині проходження конкурсу на зайняття вакантної посади державної служби. Для цього необхідно пройти комп'ютерне тестування у вигляді тесту з 40 питань на знання низькі законодавчих актів, перелік яких наведено на офіційному сайті Національного агентства України з питань державної служби. Але ці питання носять загальний характер і не відо- бражують якість отриманих знань певному виду діяльності кожного окремого органу державної служби. Тому вважаємо, що необхідно розробляти спеціалізовані тести для кожного окремого органу державної служби, з метою підготовки та добору більш кваліфікованих кадрів.

Висновки і перспективи подальших досліджень. В постмодерному суспільстві важливу роль у розвитку публічного управління відіграє теорія архетипів, яка $є$ важливим чинником формування світогляду та подальшого розвитку націй. Державна казначейська служба України в сучасному постмодерному суспільстві забезпечує ефективне та результативне надання публічних послуг. Необхідно відмітити, що з урахуванням проведеного узагальнення теоретичних підходів науковців до виконання функцій органами Казначейства запропоновано закріпити на законодавчому рівні такі функції: нормотворча; обслуговуюча; облікова; контрольна; профілактична (превентивна); інформаційна; управлінська. Обгрунтовано необхідність виділення обслуговуючої функції. Також в постмодерному суспільстві актуальними залишаються питання щодо здійснення професійного навчання працівників органів Казначейства, яке нерозривне пов'язане 3 ефективним функціонуванням органів Казначейства, тому нами детальніше висвітлено програми за якими працівники можуть проходити навчання. Крім того, проведено аналіз процедури відбору для вступу на державну службу в органи Казначейства та виявлено суттєві недоліки, які запропоновано усунути 
для більш якісного кадрового забезпечення Державної казначейської служби України.

\section{СПИСОК ВИКОРИСТАНИХ ДЖЕРЕЛ}

1. Конспект лекцій 3 дисципліни “Філософія" / [О. Романовський, Н. Кругла, Ю. Ватуля, Л. Владімирова] [Електронний ресурс]. Режим доступу : https://studfile.net/ preview/5064270/

2. Бойченко І. Філософія історії : підруч. Х. : Прапор, 2006. 656 с.

3. Про затвердження Положення про Державну казначейську службу України [Електронний ресурс] : Постанова Кабінету Міністрів України від 15.04.2015 р. № 215. Режим доступу : https://zakon.rada.gov.ua/ laws/show/215-2015-\%D0\%BF

4. Клітенко I. Ю. Дослідження розвитку функцій Державного казначейства України в умовах трансформаційних процесів державного управління коштами / I. Ю. Клітенко // [Електронний ресурс]. Режим доступу : http://www. nbuv.gov.ua/old_jrn/natural/vcpi/ Apu/2011_15/10_15_2011.html

5. Прекрасна О. I. Функції Державної казначейської служби України: [Електронний ресурс] : Режим доступу : http://www.google.com/url? $\mathrm{sa}=\mathrm{t} \& \mathrm{rct}=\mathrm{j} \& \mathrm{q}=\& \mathrm{esrc}=\mathrm{s} \&$ source $=\mathrm{we}$ $\mathrm{b} \& \mathrm{~cd}=3 \& \mathrm{ved}=2$ ahUKEwjCorfyuuX lAhUv06YKHf2ICsgQFjACegQIA hAC\&url=http $\% 3 \mathrm{~A} \% 2 \mathrm{~F} \% 2 \mathrm{Fer}$.nau. edu.ua\%2Fbitstream\%2FNAU\%2F $13824 \% 2 \mathrm{~F} 1 \% 2 \mathrm{~F} \% 25 \mathrm{D} 0 \% 259 \mathrm{~F} \% 25$ D1\%2580\%25D0\%25B5\%25D0\%25 BA\%25D1\%2580\%25D0\%25B0\%25 D1\%2581\%25D0\%25BD\%25D0\%2 5B0.doc\&usg $=$ AOvVaw36bgJmEymweNQvljiH1Zn

6. Сушко Н. I. Функції Державної казначейської служби України: ме- тодологічний та організаційний аспекти / Н. І. Сушко // Молодий вчений. 2017. № 9 (49). С. 563-566.

7. Про затвердження Положення про систему професійного навчання державних службовців, голів місцевих державних адміністрацій, їх перших заступників та заступників, посадових осіб місцевого самоврядування та депутатів місцевих рад [Електронний ресурс] : Постанова Кабінету Міністрів України від 06.02.2019 р. № 106. Режим доступу : https://zakon.rada.gov.ua/laws/ show/106-2019-\%D0\%BF

\section{REFERENCES}

1. Romanovskyi, O., Kruhla, N., Vatulia, Yu., Vladimyrova, L. (2019). Konspekt lektsii z dystsypliny "Filosofiia" [Summary of lectures on "Philosophy"]. Smila. Retrieved from https:// studfile.net/preview/5064270/ [in Ukrainian].

2. Boichenko, I. (2006). Filosofiia istorii [Philosophy of history]. Kharkiv: Prapor [in Ukrainian].

3. Postanova Kabinetu Ministriv Ukrainy "Pro zatverdzhennia Polozhennia pro Derzhavnu kaznacheisku sluzhbu Ukrainy” : vid 15.04.2015 r., № 215 [Resolution of the Cabinet of Ministers of Ukraine "On Approval of the Regulation on the State Treasury Service of Ukraine” from 21.04.2015, № 215]. (n.d.). zakon.rada.gov.ua. Retrieved from https://zakon.rada.gov.ua/laws/ show/215-2015-\%D0\%BF [in Ukrainian].

4. Klitenko, I. Yu. (n.d.). Doslidzhennia rozvytku funktsii Derzhavnoho kaznacheistva Ukrainy v umovakh transformatsiinykh protsesiv derzhavnoho upravlinnia koshtamy [Investigation of the Development of Functions of the State Treasury of Ukraine in the Conditions of Transformation Processes of 
State Fund Management]. www.nbuv. gov.ua. Retrieved from http://www. nbuv.gov.ua/old jrn/natural/vcpi/ Apu/2011_15/10_15_2011.html [in Ukrainian].

5. Prekrasna, O. I. (n.d.). Funktsii Derzhavnoi kaznacheiskoi sluzhby Ukrainy [Functions of the State Treasury Service of Ukraine]. er.nau.edu. ua. Retrieved from http://er.nau.edu. ua/bitstream/NAU/13824/1/\%D0\% 9F\%D1\%80\%D0\%B5\%D0\%BA\%D1 $\% 80 \% \mathrm{D} 0 \% \mathrm{~B} 0 \% \mathrm{D} 1 \% 81 \% \mathrm{D} 0 \% \mathrm{BD} \% \mathrm{D}$ $0 \%$ B0.doc [in Ukrainian]

6. Sushko, N. I. (2017). Funktsii Derzhavnoi kaznacheiskoi sluzhby Ukrainy: metodolohichnyi ta orhanizatsiinyi aspekty [Functions of the State Treasury Service of Ukraine: Methodological and Organizational Aspects]. Molodyi vchenyi - Young Scientist, 9(49), 563-566 [in Ukrainian].
7. Postanova Kabinetu Ministriv Ukrainy "Pro zatverdzhennia Polozhennia pro systemu profesiinoho navchannia derzhavnykh sluzhbovtsiv, holiv mistsevykh derzhavnykh administratsii, yikh pershykh zastupnykiv ta zastupnykiv, posadovykh osib mistsevoho samovriaduvannia ta deputativ mistsevykh rad" : vid 06.02.2019, № 106 [Resolution of the Cabinet of Ministers of Ukraine "On approving the Regulation on the system of professional training of civil servants, heads of local state administrations, their first deputies and deputies, officials of local self-government and deputies of local councils" : from 06.02.2019, № 106]. (n.d.). zakon. rada.gov.ua. Retrieved from https:// zakon.rada.gov.ua/laws/show/1062019-\%D0\%BF [in Ukrainian]. 